Araştırma Makalesi / Research Article

Peyzaj Mimarlığı /

Landscape Architecture

DOI: 10.21597/jist.521296
Iğdır Üniversitesi Fen Bilimleri Enstitüsü Dergisi, 9(4): 2246-2254, 2019

Journal of the Institute of Science and Technology, 9(4): 2246-2254, 2019

\title{
Evaluation of the Students' Perception about Landscape Sustainability at Istanbul Technical University
}

\section{Sahar POUYA ${ }^{1}$}

\begin{abstract}
Using a large amount of land, energy, and material, universities have a major effect on sustainability in particular environmental sustainability. Over the last decade, a large number of green projects have been performed in the campus of leading universities. The matter is that sustainability of the campuses cannot be achieved without considering the student's dimension including their perception, preferences, evaluation, and participation. The aim of this work is to analyze the relationship between the students' perception and the efficiency of sustainability programs especially sustainable landscaping on the university campuses. This work surveys the ITU's students' attitudes and perspectives about what has been operated as the sustainable landscape on the green open lands and also their preferences of the campus landscape considering what they know about sustainability concept. To perform the research, 100 students of ITU were asked to complete a questionnaire including various parts covering the subject. This research strongly suggests that universities should provide the students with the practical programs and opportunities for cooperation on the campus so that they can participate in the programs aiming for sustainability improvement.
\end{abstract}

Keywords: Green Campus; Landscape Sustainability; Students' Perception, Istanbul Technical University, Turkey

\footnotetext{
${ }^{1}$ Sahar POUYA (Orcid ID: 0000-0001-9790-9541), Urban and Regional Planning, Graduate School of Sience Engineering and Technology, Istanbul Technical University, 34437/Istanbul, Turkey

*Sorumlu Yazar / Corresponding Author: Sahar Pouya, e-mail: pouya@itu.edu.tr
} 


\section{INTRODUCTION}

Universities using a large amount of energy, water, and land have had negative impacts on the environment. However, they as the main centers of learning and education can be the ideal places to test out concepts of sustainability (Ferrer-Balas et al., 2008). In addition, universities can be considered a role model of environmental sustainability by leading practices such as resource conservation, biodiversity protection, recycling, waste reduction, water management as well as various educational programs (WCED, 1987).

The universities' campuses have consisted of large open spaces where can be considered as ideal places to locate various green sustainability projects (U.S. Green Building Council, 2017). The open spaces of the campuses can be perceived as an ecosystem with its own microclimate and valuable habitats for native plants and animals that preserve local biodiversity (Razman et al., 2017). There are various examples of the universities campuses leading sustainability programs and green projects. For instance, trying to preserve its natural areas, the Buttler University located in Indiana/ USA introduced native species and removed the invasive species by the cooperation of employees and students (IWF, 2014). The University of California, Santa Barbara (USCB) has also achieved a comprehensive sustainable plan (Byrn et al., 2013). To improve the quality of the open space network, Seattle University's campus has got an attractive green space that replaces formal lawn spaces into the street grid in order to increase the campus's green space (Chan et al., 2009). The University of Victoria provides a social media for communications with an updated website to allow for sustainability information to reach more students (University of Victoria Sustainability Website, 2016). In this way, some universities could manage their natural resources and mitigate their impact on the environment by sustainable landscaping (Chiesura, 2004; SSI, 2009). In table 1 , some strategies and factors considered for sustainability of open green lands on the campuses are listed.

Table 1. List of the most common sustainability projects performed in the landscape and open lands of the universities' campuses

\begin{tabular}{ll}
\hline \multicolumn{1}{c}{ Functions } & \multicolumn{1}{c}{ Green initiatives } \\
\hline Saving Energy & Composting, Bicycle Program, Roof garden (Velazquez et al., 2006) \\
\hline Water Conservation & $\begin{array}{l}\text { Irrigation techniques (Patrick et al., 2008), Rain water harvesting, Roof gardens } \\
\text { (Velazquez et al., 2006) }\end{array}$ \\
\hline Soil Conservation & Native Species Plant Selection, Rain garden \\
\hline Biodiversity Protection & $\begin{array}{l}\text { Conserve Natural Areas, Tree protection, More greenspaces, Using Native Plants, } \\
\text { Gardening and farming (IWF, 2014). }\end{array}$ \\
\hline Plant Conservation & Regional/indigenous vegetation, Land use and maintenance \\
\hline Storm Water Management & Porous pavement, Roof gardens, Rain gardens, Green wall, Downspout Disconnection \\
\hline Environmental Awareness & $\begin{array}{l}\text { Recycling Awareness, Composting, Spaces for social interaction and community } \\
\text { engagement with natural surroundings (IARU, 2014). }\end{array}$ \\
\hline Waste management & Composting, Recycling bin (Byrn et al, 2013). \\
\hline Integrated pest management & $\begin{array}{l}\text { Reducing use of pesticides by community stewardship (manually) (IWF, 2014), organic } \\
\text { methods to remove pets (Patrick et al., 2008). }\end{array}$ \\
\hline
\end{tabular}

Sustainable development should be able to bring many parties together in dialogue (Adams and McNicholas, 2007), as all groups of students, parents, academicians, local communities, and state governors are essential to the transformation to sustainability (Chase, 2004; Zou et al., 2015). However, in the most cases where attempts are made to implement some sustainability initiatives on the campuses, the students' involvement has been ignored (Abubakar et al., 2016). While, the 
students as the main members using the universities' campuses should be involved in the practical projects of any sustainability programs in order to foster their perceptions toward the subject and increase their environmental knowledge. The students' participation in the green projects of the campus will also encourage them to use the proposed spaces on the campus while understanding the environmental function of those spaces.

To determine the importance of the student's perceptions and their participation in succeeding the sustainability projects, main green campus of Istanbul Technical University (ITU) is chosen as a case study. In the main Campus of ITU, a series of green activities and renovations have been recently performed regarding the sustainability principles. This work makes attempt to evaluate and analyze the student's attitudes and attitudes about the sustainable initiatives established in the open lands of the ITU campus as well as achieving their level of environmental knowledge. On the basis of the students' behaviors and perceptions, it is going to provide some strategies that can help the ITU campus improve the sustainability of its landscape in particular.

\section{MATERIALS AND METHODS}

Maslak Campus as the main green campus of Istanbul Technical University has achieved significant green projects in terms of sustainability principles over the last years. Greenery, animal and plants protection, forestry, sustainable waste and water management, lightening, planting of native species are some of those green activities on the ITU campus. It seems that the next step is to analyze the influence of the implemented green projects on the ITU's students both their behaviors and implications. To do so, in this research, a qualitative method was used that consists of two techniques; observational analysis and questionnaire.

In the observational analysis, the initiatives and renovations performed in the Maslak Campus of ITU were analyzed. Its information has been achieved from both field study and ITU's website. The number of respondents considered for doing questionnaire is 100 students, who were doing their bachelor at ITU. According to the 13,000 number of the postgraduates studying at ITU, a sample size of 100-95 students seemed an adequate size (Confidence level: $95 \%$ ). The students who were asked by the questionnaire include 50 students using the inside of the buildings (covered areas) and 50 students using the open areas of the campus. Among them, responses of 95 students were analyzed, in which $37 \%$ were at first class, $23 \%$ at second class, 5 $\%$ at third class, and $25 \%$ of them were at their last year of university. Almost $89 \%$ of the students were doing their bachelor degree in one of the engineering fields.

\section{Green Initiatives}

Sustainable landscaping as a part of Green Campus Projects has been initiated in Istanbul Technical University (ITU) with the cooperation of Istanbul Regional Directorate of Forestry, Istanbul Metropolitan Municipality, and landscape department academicians of architecture faculty since 2015 (ITU Yesil Kampus, 2017). The main green activities implemented on the main campus of ITU (Maslak) include:

Land Use management: It gives priority to pedestrian and bicycle users and provides convenient circulation for the disabled users through the campus. 6 kilometers of the planned cycle and pedestrian way have been constructed on the Maslak campus (Pouya et al, 2018).

Native Plant Selection: Plant species with little water need were preferred for planting in the campus. The native vegetation and trees found on the campus were listed and classified. Infected and unhealthy trees have been moved to the new areas where they can grow better and replaced with the strong species.

Afforestation: New afforestation began considering the sunlight intensity, soil properties, and appropriate distance of planting to generate 
rich biodiversity and healthy plants on the Maslak Campus.

Irrigation System Management: Irrigation system was replaced with new technology which is set up based on the water need of the plants and can reduce the water consumption.
Rain Water Harvesting: rain gardens were implemented in some part of the campus (Figure 1). With the usage of plants that have high water holding capacity, the rainwater is absorbed and conducted into channels and finally discharged into the Golet - a huge pond located in the North of the campus.

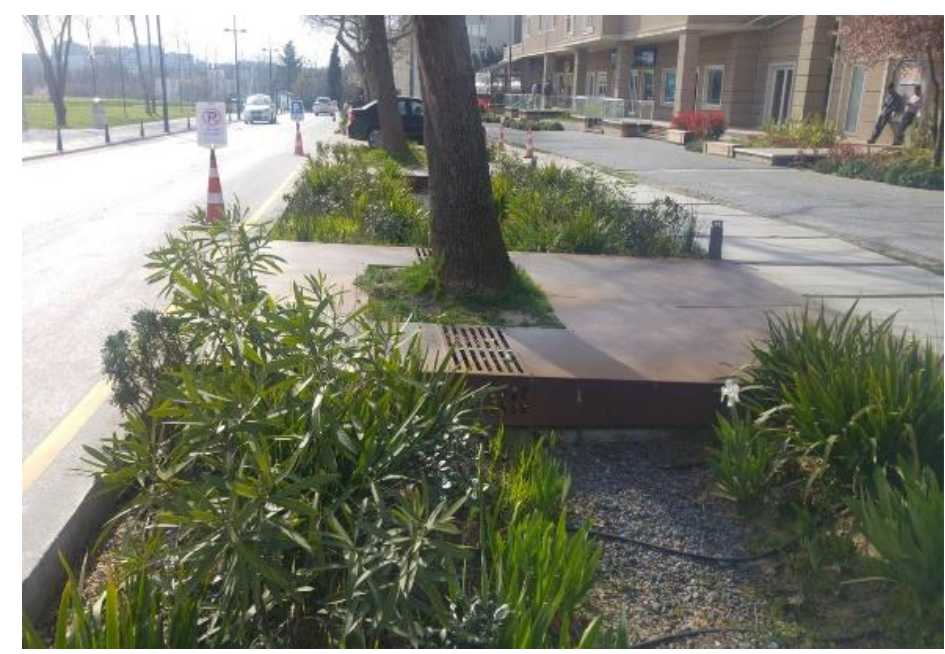

Figure 1. The rain garden in front of the Selfish Café in Maslak Campus, ITU

Energy Consumption: A safe, economic and aesthetic lighting approach with using Light Emitting Diode (LED) technology and long- life lighting has been adopted and applied in the campus that could increase place identity as well.

Permeable Concrete: Permeable concrete introduced by the faculty of civil engineering at ITU, was used in the campus. By application of this kind of concrete, there is no mud and water when it rains. So, walkability of the land is kept in different weather situations in the campus.
Water Conservation: A huge pond is known Golet is located on the Maslak Campus which is filled by the rainwater flows (Figure 2). Biofilter method was used for cleaning the rainwater accumulated in the pond. The pond water is transferred to the irrigation systems with minimum energy consumption by taking advantage of the topography when drought is experienced.

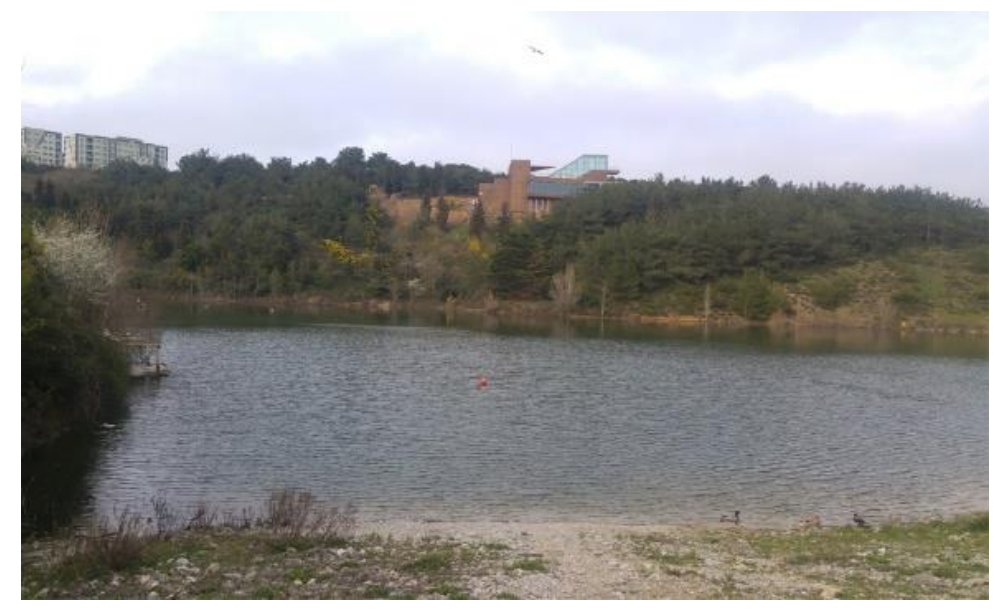

Figure 2. Golet Pond located in the north part of the Maslak campus at ITU 
Material Selection: The growth of the plants has been supported by using Corten (a corrosion resistant steel) covering the materials used in the campus green lands. The Corten is washed from the material surface in the rainy weather and penetrates into the soil and feeds the plants. This rusted metal can act as fertilizer that has some benefits for the plants and lawn.

Waste Management: For recycling of daily wastes, some definite recycling boxes which separate paper, plastic and glass waste were located in the Maslak Campus.

Car Parking Management: In order to have minimum carbon emissions within the campus, student and guest car parks were moved to central locations and the service vehicles were also directed to a remote area of the campus.

Wildlife Protection: To protect the biological diversity of the Golet, all of the bird community, the fish species, butterflies, and beetles were studied and recorded. Furthermore, dogs and cats all were vaccinated and some cabins were built to meet their eating and drinking needs. Bird nests in suitable sizes and types were also installed on the trees for the sparrows all over the campus.

\section{Questionnaire}

The questionnaire technique involves three main parts from general questions to the more specific ones. The first part of the questionnaire is related to the behavioral attitudes of the students which include some questions about the students' transportation ways, their ways of spending time, and their main activities on the campus. The second part is composed of some questions about the students' perceptions of the sustainability concept and its importance in various environmental items. In the last part, the students were able to express their level of agreement or disagreement for each expression including various aspects of the Maslak open lands such as its green environment, biodiversity, transportation, materials, pavement, facilities, and accessibility.

\section{RESULTS AND DISCUSSION}

\section{Students' Behavior and Preference}

Walking is the main way of students' movement on the campus. According to the answers of the students, $77 \%$ of the students walk through the campus to reach the various parts of the university. However, $15 \%$ of the students use the bus services of the campus and Just $3 \%$ of the students ride the bicycle on the campus (Figure $3)$.

Around $57 \%$ of the students responded that they do not have any bicycle. $10 \%$ of them do not feel the need of using a bicycle on the campus, because of not living in the campus dormitory and short distances between departments. Other reasons about not using bicycles are related to land structure and its high slop, intervention by dogs on the way, lack of security, and enough space on bicycle parking lots of the campus.

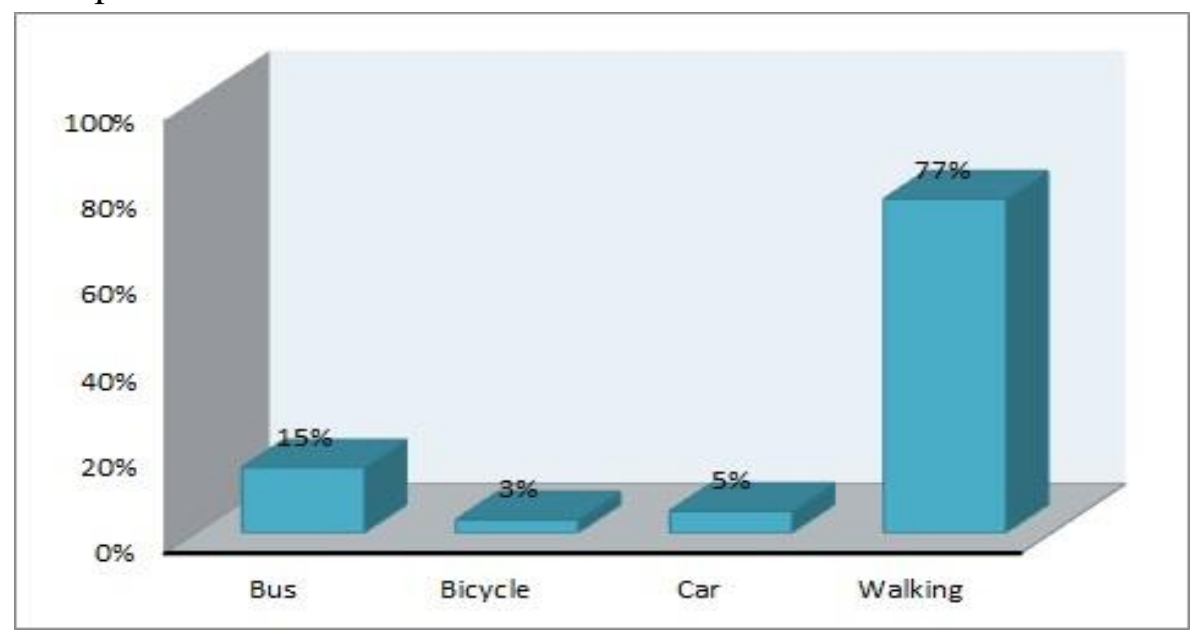

Figure 3. Students' transportation and movement to the various parts on the Maslak Campus of ITU. 
Most of the students spend around 2 hours with aim of recreation beyond the time of studying and eating when they are in the university and $17 \%$ of them spend more than 2 hours. It means that more than half of the students do recreation for around 2 hours in a day when they are on the campus.

Choosing among five main activities that the students do on the campus, eating and talking with friends were defined as two main activities in the Maslak Campus. Studying, playing sport, and walking on the campus are the other activities respectively

Based on the students' answers, open green lands of the campus are not used for various activities of the students. Green lands of the campus are mostly used for walking (85\%) of the students. Just $13 \%$ of studying and $10 \%$ of sports are performed and played on the green lands of campus.

\section{Student's Perceptions \\ Perception of sustainability concept}

Based on the students' responses, $60 \%$ of the students know about the sustainability concept in which $37 \%$ of them have gained their information through Internet resources. A small number of the students has caught about the issue through their practical experiences.

Giving priority to the importance of sustainability in four items of the economy, environment, transportation, and construction, around $70 \%$ of the students gave first priority to the environmental sustainability and second place was designated to the transportation sustainability (Figure 4).

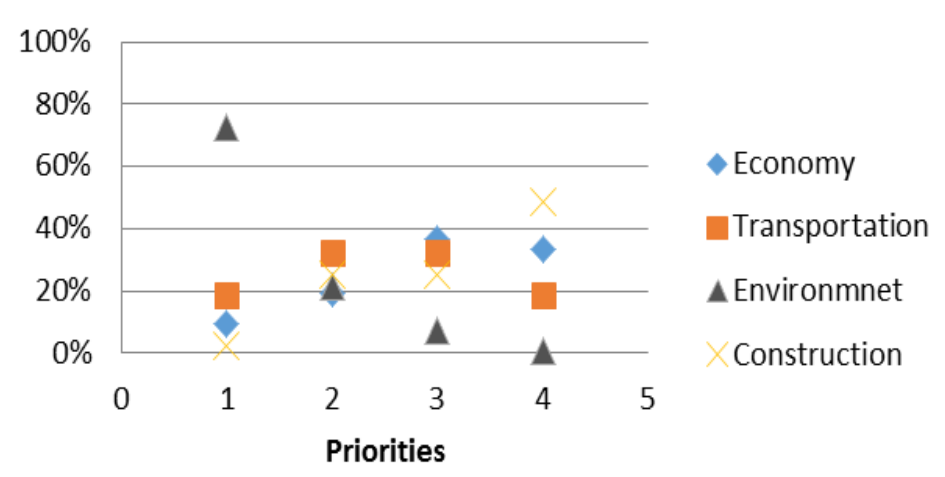

Figure 4. Priority of the students given to the importance of sustainability in various items including economy, environment, transportation, and construction.

Subsequently, the students were asked to give priority to the sustainability of six main elements of the environment including Oxygen, water, soil, plants, energy, and animal. Oxygen
(45\%) and Energy (30\%) were selected as the first priority and Water as the second priority. Soil, plants, and animals are considered for the other priorities respectively (Figure 5).

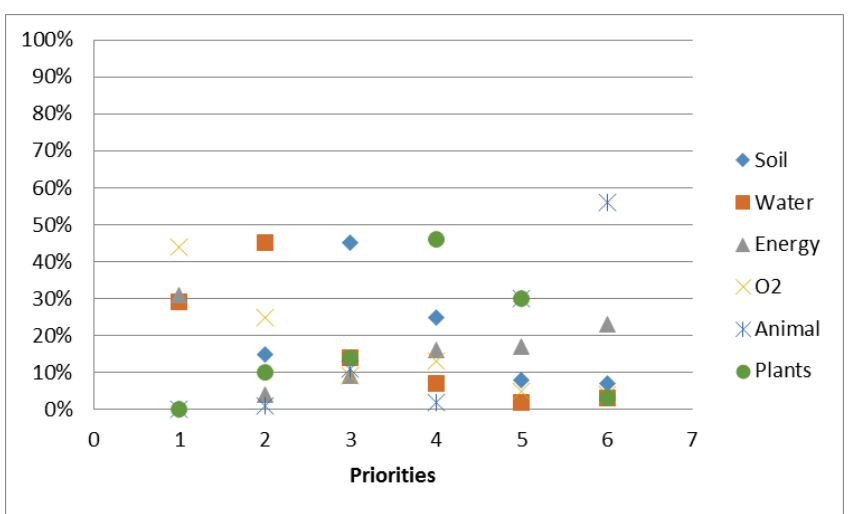

Figure 5. Priority of the students given to the six main elements of the environment based on the students' answers 


\section{Perception of Maslak Campus sustainability}

According to the answers of the students, $96 \%$ of the students think that green open lands of Maslak campus should be sustainable over time. It means that the students understand the importance of the issue; however, $60 \%$ of the students have no information about any green initiatives performed on the Maslak campus. Only $37 \%$ of the students have noticed and understood about the achievements of sustainability in the green campus of Maslak.
It was determined through the student's answers that most of the students, who noticed about the green initiatives in the Maslak campus, could get informed about it through walking on the campus $20 \%$ of the students got informed by ITU website and $10 \%$ of the students have known about the green initiatives by their educational programs (Figure 6). It can be inferred that the ITU's various departments didn't participate in sustainability programs of the university.

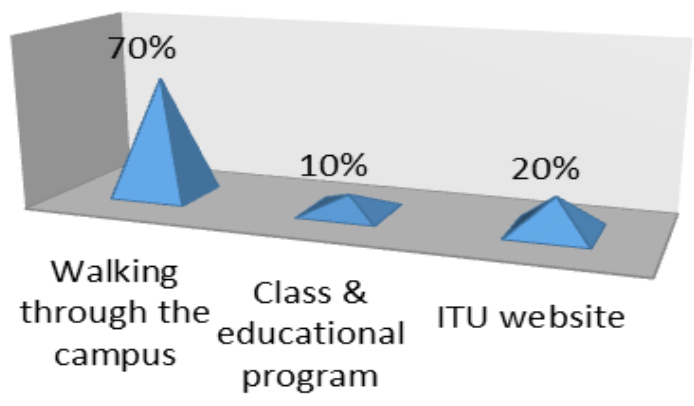

Figure 6. Ways that helps the students know about green initiative in the Maslak Campus

\section{Students' evaluation of sustainable landscaping on the Maslak Campus}

More than half of the students think that the greenery covering in the Maslak campus is enough to produce Oxygen and absorb $\mathrm{CO}_{2} .49 \%$ of the responders agree that planting of the campus is sustainable which may be inferred that around half of the students think that the university has enough plants and green lands. However, about plant selection on the campus, $48 \%$ of students are not sure that trees were planted with regard to their needs and place characteristics. Similarly, $62 \%$ of the ITU's students do not know about using native plants in the campus. It may mean that it was not given to the students enough information about various kinds of plants existing in the campus and they were not provided with the opportunity to participate in the sustainable planting projects of ITU.
Students have different perception about animal and plant protection in the campus. According to the answers, most of the students are not confident about plant protection of the campus and $30 \%$ of the students think that the campus doesn't protect plants. They may have confronted with some events of falling trees in the campus. The ITU Maslak campus has been preformed some forestry projects over the campus, however in some part of the campus; trees are in bad condition of protection. About the wildlife protection in the campus, $44 \%$ of students think that university protects animal and wildlife.

About using sustainable technologies and materials on the campus, the ITU's students are not informed enough. As for water management, $47 \%$ of the students have not noticed to the types of irrigation system used in the campus. Furthermore, $35 \%$ of them do not have information about the material sustainability of 
the sitting elements on the campus. Similarly, $32 \%$ of the students are not sure about the porosity of the pavement and $27 \%$ of students do not agree that the pavement absorbs the runoff and rainwater. About the lighting system, almost half of the students do not know how the lights of the campus work and where their energy comes from. Even though the campus has started using Light Emitting Diode (LED) technology and long life lighting products, the students were not informed about the energy consumption of the lights on the campus.

However, most of the students agree with some aspects of landscape sustainability in the campus. For instance, about the bicycle path, most of the students think that the campus of Maslak campus gives the students the opportunity to ride a bicycle. Furthermore, $74 \%$ of the students believe that there are a good accessibility and connectivity by car to the places on the campus. Half of the students think that the lawn used in the open lands of Maslak campus are stable in front of walking. About the waste management, $56 \%$ of the students think that the university campus has recycling bins. But, 99\% among them think that the recycling trash bins are not enough or are not distributed well. Regarding the students' perceptions obtained by the questionnaires, some strategies can be suggested to improve the landscape sustainability of the ITU's campus.

One of the main strategies to improve the students' awareness of environmental sustainability in the campus is to discover how the students move over the campus. Walking of $80 \%$ of the students over the campus means that they almost pass through the green open lands on foot and ITU can increase the students' knowledge about its green implementations by installing informational billboards on the way of the students.

On the Maslak Campus of ITU, just 3\% of the students use the bicycle in the campus, while a great bicycle cycle was designated to the bicycles riders on the Maslak campus. The university can increase the use of the bicycle by providing free bike lending programs, bike parking security, and bicycle repair workshops. As most of the students do recreation for 2-3 hours in a day on the ITU campus, riding a bicycle over the campus can be considered as a great recreation program for them.

ITU's students do not use the green open lands of the campus as much as the covered places. According to results of this research, this preference is not related to the quality of the green open lands itself, as most of the students are satisfied with the cooling effect, greenery, and quietness of the campus green lands. The reason of not using the green lands in ITU is lack of the facilities such as appropriate sitting places for the students and their group activities in particular. Green open lands have to be provided with the same facilities as the covered places in order to meet the students' needs.

However, almost all of the ITU's students agree with the sustainability of the university and its green open lands in particular. They also gave the first priory to sustaining environment and energy. It may mean that the students are probably more interested and motivated to participate in a green program of the campus.

\section{CONCLUSION}

Considering a large amount of the open spaces in the main campus of the universities, the campus landscapes include diverse green initiatives from energy reduction and waste recycling toward the environmental conservation. Despite the undeniable contribution of those green initiatives to the environmental sustainability, the campus landscape can convey important messages of the sustainability issue to the students as the main users of the campuses. However, it seems this dimension of the green actions is not considered in the processes of evaluation and analysis before or/and after the sustainability initiatives are established in the universities. Various plans for a well-organized student's participation on the campus may be 
thought. Student-based organizations, students meetings including hearings, academics-students surveys through workshops, charters, and brainstorms sessions, information propagation through service announcements, press releases (fliers, reports, newsletters), oral briefings, and regular exhibits can be included in the collaborative campus designing. Cooperative design of the campus area can help generate feelings of ownership and create fundamentally better ideas in the future, too.

\section{REFERENCES}

Adams AC, McNicholas P, 2007. Making a difference: Sustainability reporting, accountability and organizational change, Accounting, Auditing \& Accountability Journal, 20(3): 382-402, https://doi.org/10.1108/09513570710748553.

Abubakar RI, Al-Shihri SF, Ahmed MS, 2016. Students' Assessment of Campus Sustainability at the University of Dammam, Saudi Arabia, Sustainability, 8 (59); doi:10.3390/su8010059.

Amr IA, Kamel Sh, Gohary ElG, Hamhaber J, 2016. Water as an Ecological Factor for a Sustainable Campus Landscape, Procedia - Social and Behavioral Sciences, $216 \quad$ (6): 181-193, https://doi.org/10.1016/j.sbspro.2015.12.027.

Byrn M, Endicott M, Kokosinski K, Lovegreen M, Bill N, 2013. Campus Sustainability Plan, University of California; Santa Barbaram, 18-23.

Barlett PF, Chase GW, 2004. Sustainability on Campus: Stories and Strategies for Change; MIT Press: Cambridge, MA, USA.

Brundtland GH, 1987. Our Common Future: Report of the World Commission on Environment and Development. Oxford University.

Chan M, Coupland W, Gagesch K, Mulé C, Runyan A, 2009. Exploring Sustainability in Campus Design and Greenspace: Lessons from Leading Universities. http://environment.utoronto.ca/Upload/Undergradu ateResearchReports/421GreenSpace08-09.pdf.

Chiesura A, 2014. The role of urban parks for the sustainable city, Landscape and Urban Planning, 68: 129-38.

Ferrer-Balas JD, Adachi S, Banas CI, Davidson A, Hoshikoshi A, Mishra Y, Motodoa M, Onga M Ostwald,. 2008. An international comparative analysis of sustainability transformation across seven universities. International Journal of Sustainability in Higher Education,9(3): 295 - 316: http://dx.doi.org/10.1108/14676370810885907.

Green Campus, Available online: http://www.yesilkampus.itu.edu.tr/yesil-kampus (Accessed on 21 May 2017).
Huang L, Wu J, Yan L, 2015. Defining and measuring urban sustainability: a review of indicators, Landscape Ecol, 30: 1175-1193. DOI 10.1007/s10980-015-0208-2.

Indiana Wild Life Federation. (IWF). 2014. Butler Sustainability, Sustainable Landscaping at Butler University Part of the Indiana Wildlife: Federation's Landscaping the Sustainable Campus program, Available online: www.indianawildlife.org (accessed on 20 Jan. 2018).

International Alliance of Research Universities (IARU), 2014. Green guide for universities, IARU pathways towards sustainability, Available online: http://www.iaruni.org/about/about-iaru (accessed on 10 Jan. 2018).

ITU Green Campus, Available online: http://www.yesilkampus.itu.edu.tr/yesil-kampus (Accessed on 21 May 2017)

Patrick D L, Murray T, Bowles IA, 2008. Campus Sustainability: Best Practices. Prepared for the Leading by Example Program at the Massachusetts Executive Office of Energy and Environmental Affairs.

Pouya S, Pouya S, 2018. Sustainable Landscaping in Istanbul Technical University, Turkish Journal of Forest Science 2(1): 98-114

Razman R, Abdullah HA, Wahid R Z B, Muslim R. 2016. Web Content Analysis on Sustainable Campus Operation (SCO) Initiatives, the $9^{\text {th }}$ International Unimas Stem Engineering Conference (ENCON 2016) Innovative Solutions for Engineering and Technology Challenges, Sarawak, Malaysia, 87, 12 December 2016.

Sustainable Sites Initiative (SSI): Guidelines and performance benchmarks (SSI). 2017 Available online: http://www.sustainablesites.org/ (accessed on 15 Sep. 2017).

U.S. Green Building Council, Available online: http://www.usgbc.org. (accessed on 10 December 2017)

University of Victoria. 2016. Progress Report, Sustainability Action Plan: Campus Operations, 2014 - 2019, https://www.uvic.ca/sustainability/

Velazquez L, Munguia N, Platt A, Taddei J, 2006. Sustainable university: what can be the matter? Journal of Cleaner Production,Vo. 14 (9-11): 810819; DOI10.1016/j.jclepro.2005.12.008.

WCED, 1984. Our common future. Oxford University Press, New York.

Zou Y, Zhao W, Mason RLM, 2015. Comparing Sustainable Universities between the United States and China: Cases of Indiana University and Tsinghua University, Sustainability, 7(9), doi:10.3390/su70911799. 